\title{
Intracerebellar Hemispheres Schwannoma: A Case Report
}

\section{Intraserebellar Hemisferlerde Şvannom: Bir Olgu Sunumu}

\author{
Wang XUEJIAN, Zhang XIAOBIAO, Hu FAN, Yu YONG, Gu YE, Xie TAO \\ Fudan University, Zhongshan Hospital, Department of Neurosurgery, Shanghai, China
}

Corresponding Author: Zhang XIAOBIAO / E-mail: 6841441@163.com

\begin{abstract}
Brain parenchyma schwannoma is a rare intracranial tumor, and especially rare in cerebellar hemisphere. In this report, a case of cerebellar schwannoma in a 52-year-old woman, was studied by computed tomography (CT), magnetic resonance image (MRI) and PET-CT. This tumor was totally removed by surgery. The histological diagnosis of schwannoma was confirmed by histological, $\mathrm{HE}$ and immunohistological staining examination (positivity for the S-100 protein and vimentin, and partly positivity for P53 (70 \%+), and negative for GFAP). The patient has been followed-up for more than one year, and she lives in good condition and brain MRI shows no recurrence. Surgery is the most effective treatment for cerebellar schwannoma.
\end{abstract}

KEYWORDS: Cerebellar tumor, Schwannoma, Brain parenchyma

öz

Beyin parankimi şvannomu nadir bir intrakraniyal tümördür ve serebellar hemisferlerde özellikle nadirdir. Bu raporda, 52 yaşındaki bir kadındaki serebellar şvannom bilgisayarlı tomografi (BT), manyetik rezonans görüntüleme (MRG) ve PET-BT ile incelendi. Tümör cerrahiyle tamamen çıkarıldı. Şvannom histolojik tanısı histolojik, HE ve immünohistolojik boyama incelemesiyle doğrulandı (S-100 proteini ve vimentin için pozitif ve P53 için kısmen pozitifken (70\%+) GFAP için negatifti). Hasta bir yılı aşkın süredir takip edilmektedir ve durumu iyi olup beyin MRG nüks göstermemiştir. Serebeller şvannom için en etkili tedavi cerrahidir.

ANAHTAR SÖZCÜKLER: Serebellar tümör, Şvannom, Beyin parankimi

\section{INTRODUCTION}

It is generally considered that schwannoma is derived from schwann cells which is the composition of the nerve sheath, and occurs in brain parenchyma extremely rarely. The authors reviewed the literature and found less than ten cases reported that occurred in the cerebellar hemisphere (5). In 2010, one case of cerebellar hemisphere schwannoma was treated and cured by surgery at our department.

\section{CASE REPORT}

A 52-year-old woman was admitted to our neurosurgical department with a more than one-month history of walking unsteadiness. Neurological examination showed severe ataxia, finger-to-nose test (+), Romberg sign (+), not walking in a straight line and levo-deviation. There were no cutaneous or skeletal signs of neurofibromatosis. Computerized tomography $(\mathrm{CT})$ revealed a low density and quasi-round lesion of the left cerebellar hemisphere. Brain magnetic resonance imaging (MRI) revealed a quasi-round signal in the left cerebellar hemisphere with a clear boundary and non-uniform low signal in T1WI (Figure $1 \mathrm{~A}$ ); and high signal within a little low signal in T2WI (Figure $1 \mathrm{~B}$ ); In contrastenhanced MRI, the parenchyma and capsule wall of the mass was enhanced, and not enhanced in the cystic area (Figure 1 C,D). PET-CT revealed a region of low glycometabolism in the left cerebellar hemisphere. During surgery, we found that the tumor was located under the left cerebellar hemisphere cortex; the mass had a complete capsule and clear boundary, and was located completely in the cerebellar parenchyma. Immunohistochemical studies showed positivity for the S-100 protein and vimentin, and partial positivity for P53 (70\%+), while it was negative for GFAP. The tumor was diagnosed as schwannoma accompanied by hemorrhage and cystic change (Figure 3A,B). The postoperative course was uneventful. The ataxia progressively improved. She fully recovered from illness and was discharged. She has been followed up for more than one year and she lives in a good condition. Brain MRI indicates no recurrence (Figure 2 ).

\section{DISCUSSION}

Intracranial schwannomas usually arise from the sensory branch of the cranial nerves, are most common located at the cerebellopontine angle, and are very rare in the brain parenchyma. Normal Schwann cells usually do not exist in the brain parenchyma. The histogenesis of intraparenchymal schwannomasis is still debated and has not yet been confirmed $(3,8,9)$. Reviewing the literature, we found that brain 

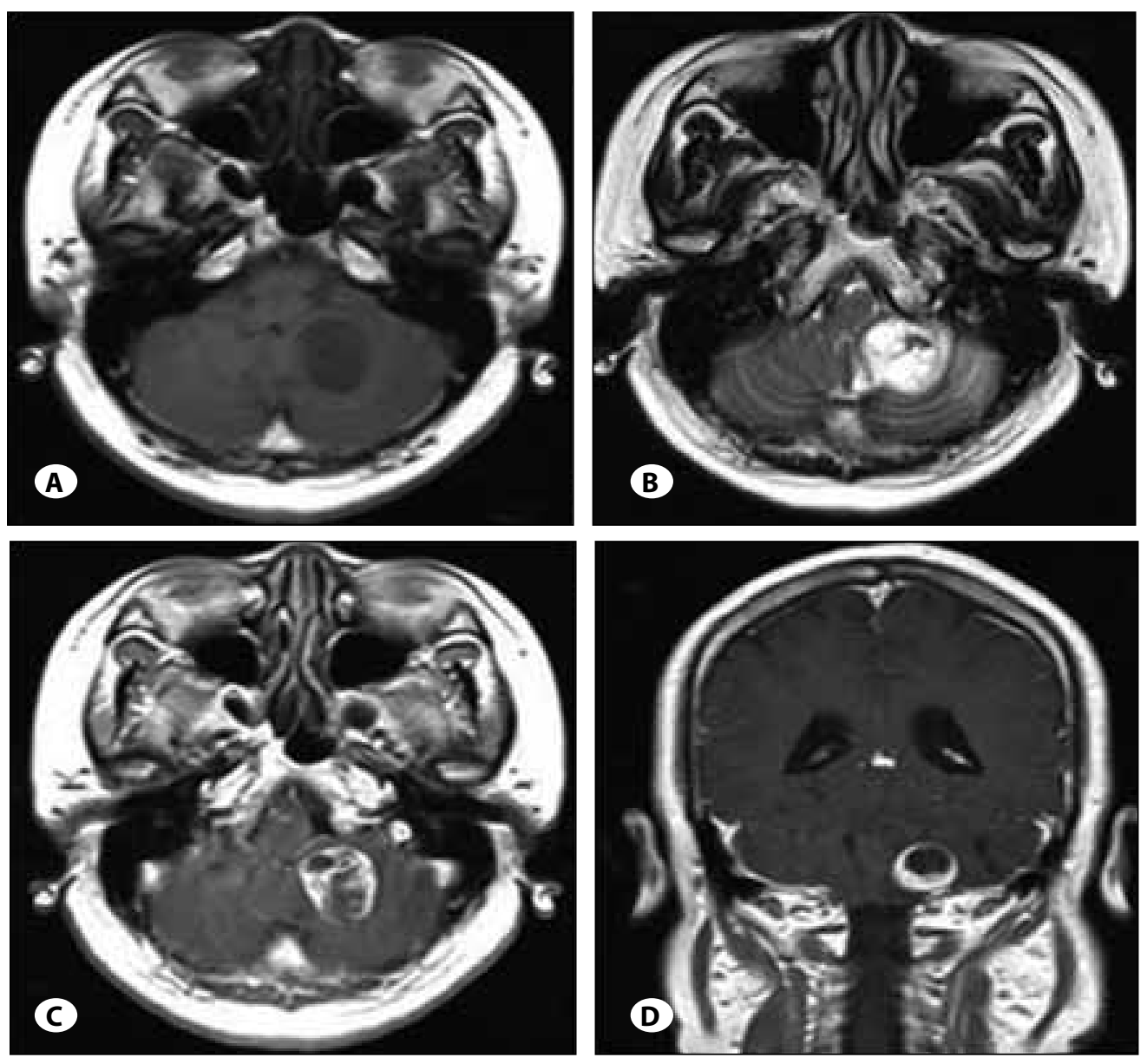

Figure 1A-D: Preoperative axial T1, axial T2, contrastenhanced axial and coronal T1-weighted magnetic resonance imaging (MRI) showing a circular cystic mass in the left cerebellar hemisphere.

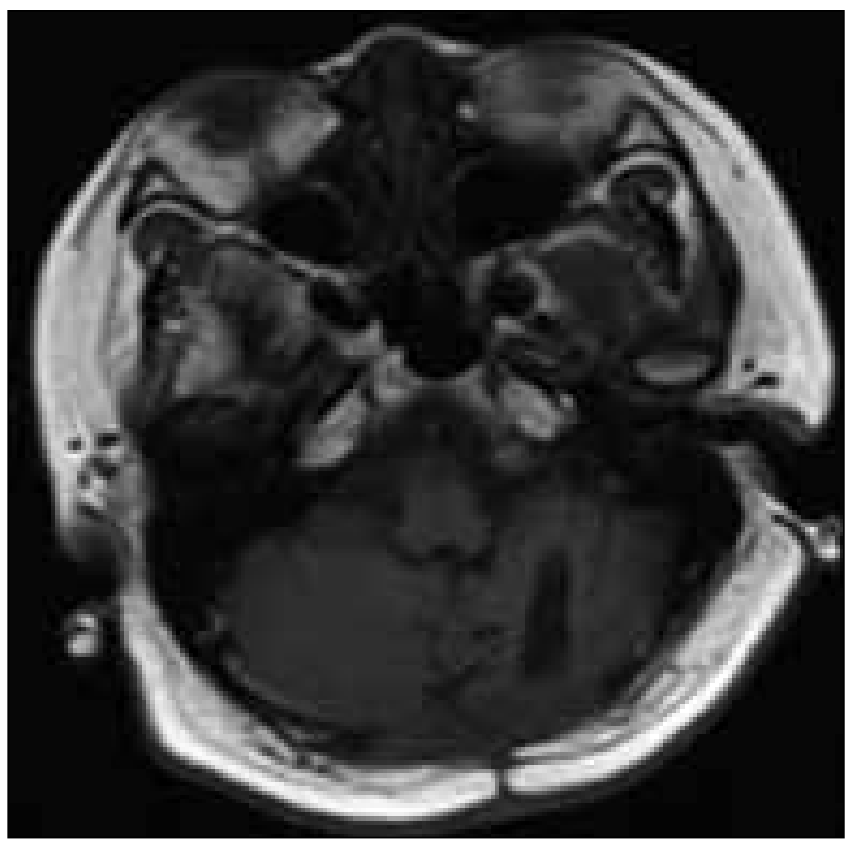

Figure 2: Postoperative T1 MRI showing no residual tumor was found and it was totally resected. parenchyma schwannomas are mainly located in the upper tentorium and less than ten cases occurred in the cerebellar hemisphere $(2,5)$. We only encountered this case of schwannoma within the brain parenchyma in our department. Age of onset varies for brain parenchymal schwannoma and it is more common in adults (7). CT and brain MRI examination showed characteristic changes, such as cystic tumor, calcification, and peritumoral brain edema $(2,4)$. Imaging manifestations of brain parenchymal schwannoma is exactly the same as acoustic schwannoma and other nerve sheath tumors outside the brain. It is just located at a special site. Like acoustic nerve sheath tumors, it can show single or multiple intratumoral cystic changes of unequal size (3). The formation of cystic tumors may be due to micro-hemorrhage, necrosis, or decay, leading to creation of a small pouch, and then a confluent capsule (7). The majority of the tumors are benign, and show clinical symptoms related to their host site. Clinical symptoms and imaging manifestations of this tumor are not specific, so the diagnosis of brain parenchymal schwannoma must be verified by both histology and immunohistochemical studies. Immunohistochemistry shows S100 (+), VIM (+), GFAP $(-)$ and so on $(4,5)$. The tumor is located in the brain parenchyma, and has no obvious relationship with the surrounding dura and cranial nerve. Most cases can be totally removed. The prognosis of this tumor is good and no radiotherapy 

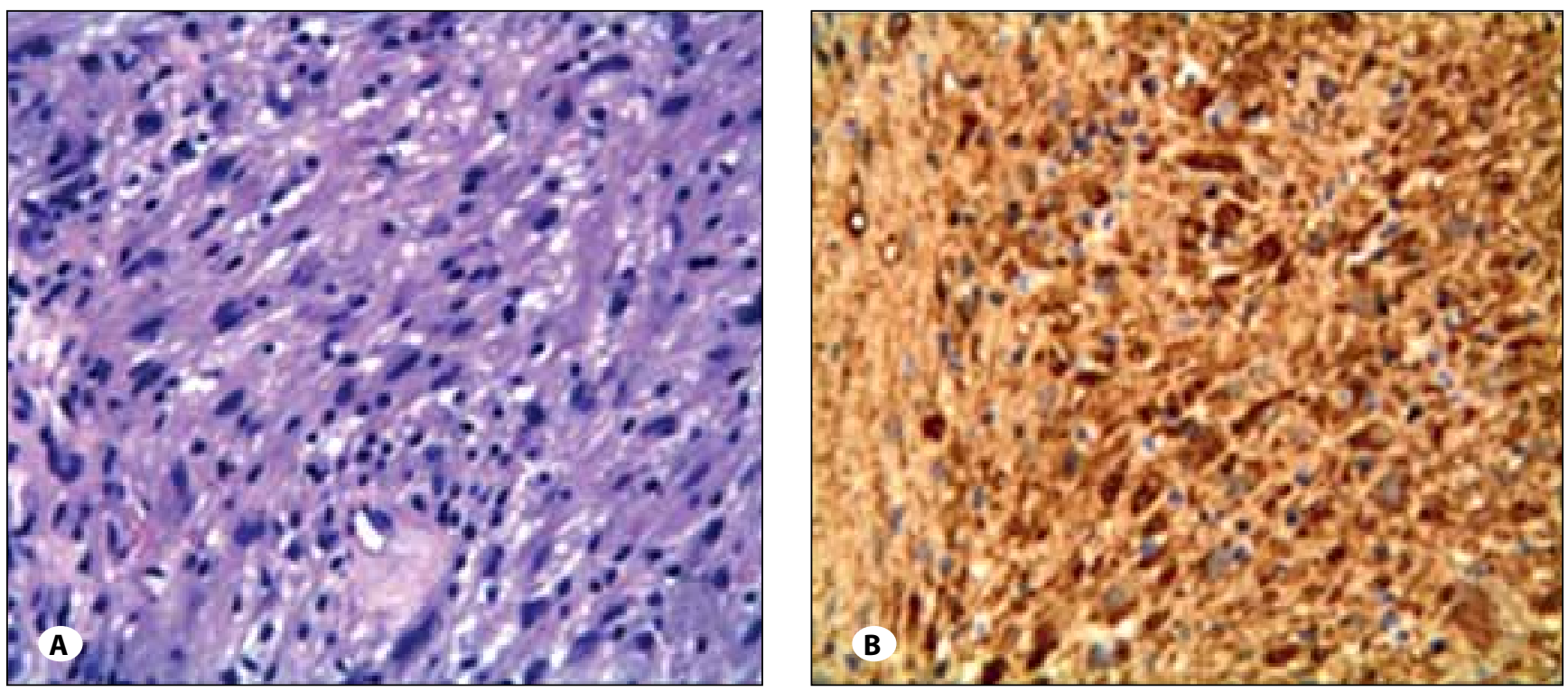

Figure 3: Biopsy prompts schwannoma, A) HE stain (400x), B) positive S-100 in immunohistochemistry (400x).

or chemotherapy is needed. For schwannoma in the brain parenchyma, it is difficult to achieve a correct diagnosis by relying solely on preoperative imaging studies $(1,7)$. Differentiation is generally with glioma, metastases, and so on but it was misdiagnosed preoperatively as hemangioblastoma in this case.

\section{REFERENCES}

1. Benedict WJ Jr, Brown HG, Sivarajan G, Prabhu VC: Intraventricular schwannoma in a 15-year-old adolescent: A case report. Childs Nerv Syst 24:529-532, 2008

2. Casadei GP, Komori T, Scheithauer BW, Miller GM, Parisi JE, Kelly PJ: Intracranial parenchymal schwannoma. A clinicopathological and neuroimaging study of nine cases. J Neurosurg 79:217-222, 1993

3. Chitre MB, Rajshekhar V, Chandi SM, Chandy MJ: Cystic cerebellar schwannoma. Br J Neurosurg 6:477-479, 1992

4. Ezura $M$, Ikeda $H$, Ogawa A, Yoshimoto $T$ : Intracerebral schwannoma: Case report. Neurosurgery 30:97-100, 1992
5. Maiuri F, Colella G, D'Acunzi G, De Caro Mdel B: Malignant intracerebellar schwannoma. J Neurooncol 66:191-195, 2004

6. Singh RV, Suys S, Campbell DA, Broome JC: Malignant schwannoma of the cerebellum: Case report. Surg Neurol 39:128-132, 1993

7. Tsuiki H, Kuratsu J, Ishimaru Y, Nakahara T, Kishida K, Takamura M, Marubayashi T, Ushio Y: Intracranial intraparenchymal schwannoma: Report of three cases. Acta Neurochir (Wien) 139:756-760, 1997

8. Weiner HL, Zagzag D, Babu R, Weinreb HJ, Ransohoff J: Schwannoma of the fourth ventricle presenting with hemifacial spasm. A report of two cases. J Neurooncol 15: 37-43, 1993

9. Zagardo MT, Castellani RJ, Rees JH, Rothman MI, Zoarski $\mathrm{GH}$ : Radiologic and pathologic findings of intracerebral schwannoma. AJNR Am J Neuroradiol 19:1290-1293, 1998 